\title{
Issues of Definition and Potentialities of Transdisciplinary Approach in Post-non- classical Science
}

\author{
OKSANA KUSHNIR \\ Yuriy Fedkovych Chernivtsi National University, 2, Kotsyubynsky, 58012, Chernivtsi, Ukraine \\ Email: oksana.kushnir.93@ukr.net
}

\begin{abstract}
The main task of the article is an in-depth theoretical analysis of the transdisciplinarity phenomenon. To accomplish it, we carried out a comparative analysis of the main integrative forms of modern scientific knowledge. The basic approaches to the definition of transdisciplinarity are considered. We explored two dominant areas that stand out in Western European transdisciplinary research and methodological works: ontological and methodological. The analysis of B. Nicholescu's onto-epistemological approach led to the conclusion that, unlike particular disciplines that study specific fragments or levels of reality, a transdisciplinary strategy is an attempt to understand the dynamics of the process at several levels of reality at the same time. That is why it crosses the boundaries of specific disciplines and creates a universal picture of the process under study. The methodological framework of transdisciplinary research is outlined and its specific purpose is defined. The realization of this purpose is possible only if the respective requirements are met.
\end{abstract}

Keywords: transdisciplinarity, interdisciplinarity, multidisciplinarity, onto-epistemological approach, methodological approach

\section{INTRODUCTION}

The term 'transdisciplinarity' first appeared in the discussions of J. Piaget, E. Jantsch and A. Likhnerovich in 1970. In the framework of the international group's cooperation on the topic 'Interdisciplinarity - Studies and Research Programs at Universities', Piaget formulated the definition of transdisciplinarity as the highest (third) level in the system of knowledge integration. It comes after interdisciplinarity as a form of interaction of different disciplines aimed at interchange and enrichment and multidisciplinarity, which is a combination of disciplines to solve problems without structural changes in scientific discourse. The integration of knowledge in a transdisciplinary framework implies the creation of a common research system without rigid disciplinary boundaries (Piaget 1970: 467-528).

The next stage of theoretical understanding of the transdisciplinarity phenomenon was the UNESCO-sponsored symposium 'Science and the Frontiers of Knowledge: A Prologue 
to Our Cultural Past' (Venice, Italy, 1986). The results of the discussion on the problems of the fundamental science development, especially the natural sciences, were reflected in the Venice Declaration.

In the text of the document, particular attention was paid to the existing contradictions between science and other forms of knowledge. The participants also emphasised the need for a constructive 'epistemologically-impartial' dialogue of cognitive practices that constitute a holistic experience of human cognition.

Undoubtedly, multiple problems were major factors that increased attention to the integration possibilities of different cognitive strategies. These problems arise in modern society and require an effective cognition methodology. In the 1972 Paris Dialogue, researchers saw the starting point for the subsequent development of transdisciplinary approaches, which would help solve pressing issues.

Nowadays, the phenomenon of transdisciplinarity is theoretically grounded in several modern conceptions of philosophy and sociology of science and has been implemented in the development of transdisciplinary research centers. As a theoretical and methodological approach, transdisciplinarity has become a relevant research framework for addressing the complex problems, which arise in ecology, energy, health care, and more.

However, its research remains relevant, as there is still no clear definition and understanding of the transdisciplinarity phenomenon in modern science, which raises many problems. The reason being is that some identify transdisciplinarity with transdisciplinary science as such, others consider it the highest (third) level in the system of knowledge integration. However, transdisciplinarity is neither. It is the interaction of scientific and other forms of knowledge, which involves cognitive resources of stakeholders to effectively solve planetary problems in an era of increasing complexity and uncertainty. The search for answers about the scientific novelty and practicality of this approach, as well as the difference between transdisciplinarity and other forms of knowledge integration, determined our scientific interest in this issue and outlined our goals and objectives.

To achieve these goals, we used an integrated approach as the most relevant to the specifics of the subject. Its implementation revealed key factors in the formation of the transdisciplinarity phenomenon in the context of interconnected processes that have determined the changing role of science and its philosophy in society.

The methodological guidelines for our study are the principles of historicism, objectivity and systematic consideration of the problem. The principle of historicism allows us to take into account qualitative changes in the phenomena considered over time. The principle of objectivity states the need to take into account all the factors for a holistic theoretical analysis. The principle of systematicity is used to identify relationships between individual properties of the phenomenon under study.

The study is inter- and transdisciplinary in nature, because we used the results obtained in the sociology, history and philosophy of science, which give a holistic view that reaches the level of philosophical generalizations.

\section{INTEGRATION OF MODERN SCIENTIFIC KNOWLEDGE}

In the modern philosophy of science, as well as in the theory and practice of transdisciplinarity, there are several approaches to the phenomenon. They distinguish it from other forms of knowledge integration that are interdisciplinarity and multidisciplinarity. The question is whether transdisciplinarity is a phenomenon that is different from other (classical) cognitive strategies. 
The first classification of interaction models between knowledge and cognitive practices, which appealed to multidisciplinarity, interdisciplinarity and transdisciplinarity, was proposed during the aforementioned conference. Now, according to a comparative analysis by L. R. Lattuca, the key feature of interdisciplinarity is the intra-scientific cooperation of disciplines, whereas the indicator of a multidisciplinary approach is the imposition of disciplines. It provides the extension of knowledge and methodological knowledge autonomy of researchers (Lattuca 2003). Unlike transdisciplinarity, the specificity of multidisciplinarity is revealed when there is a tendency to consistently draw different views on a problem. It is embodied in many modern research projects and is reflected in the conference schedules (Frodeman et al. 2010: 17). According to T. Remadier, 'Multidisciplinarity and Interdisciplinarity do not violate disciplinary thinking... In the case of multidisciplinarity, the aim is to spread theoretical models of different disciplines... Interdisciplinarity differs from multidisciplinarity in that it constructs a common model for the disciplines involved, based on the dialogue between them. However, as the researcher emphasises, neither of these forms of disciplinary interaction is able to overcome the fragmentation and limitations inherent in the traditional form of organization of science. A substantially different approach to the object of the study demonstrates transdisciplinarity because it is based on controlled conflict generated by paradoxes' (Remadier 2004: 433-434). Accordingly, transdisciplinarity is seen as a relevant way of combining the capabilities of disciplinary, multidisciplinary and interdisciplinary approaches to build new object-based strategies that take into account the existence of different levels of reality.

R. J. Lawrence thinks similarly and believes that interdisciplinarity preserves disciplinary boundaries, conceptual provisions and methodological guidelines when interacting with different professionals working to solve the problem. And multidisciplinarity is associated with the integration of methodological and conceptual tools in various fields of science. In turn, transdisciplinarity is understood as a way of synthesising the resources of the disciplinary and non-disciplinary spheres. The result is a cognitive model that does not boil down to any of its components (Lawrence 2004: 488-489). The same opinion is supported by a number of authors who focus on involvement of interested groups. For instance, A. Di Giulio and R. Defila conceive transdisciplinarity as a special format of interdisciplinarity, where future users contribute substantially to the research, in addition to scholars from different academic disciplines. Thus, future users are 'experience-based experts' (or 'non-certified experts') (Di Giulio, Defila 2017; 2015). In their article, N. Rudhumbu, L. Zhou and K. Nhundu defined transdisciplinarity as interdisciplinary research plus interested groups (stakeholder, problem owners) who are involved in all phases of the research process' (Rudhumbu et al. 2017: 16). The results of rethinking the new cognitive phenomenon are observed in at least three interrelated theoretical perspectives: reassessment of ideas about the epistemological values of knowledge, ideas about the subject of knowledge and the preconditions for new theories.

In general, the distinction between transdisciplinarity and other forms of knowledge integration is related to the fact that the latter does not violate disciplinary boundaries, while transdisciplinarity implies a recourse to cognitive resources in a non-disciplinary field.

At the same time, it should be noted that the semantic closeness of the term 'transdisciplinarity' to various types of disciplinary integration, such as inter-, multi- or poly-disciplinary, does not allow one to fully reveal the specifics of the phenomenon under study. An important aspect of the latter is the prefix 'trans-', which indicates its terminological proximity 
to transgression. Some of the definitions of this term are connected with deviation, such as: 'a violation of law, principle, or duty'; 'the exceeding of due bounds or limits' (The American Heritage Dictionary of the English Language). Such interpretation makes the connotations of 'transgression' as 'forbidden by law' understandable. Therefore, in scientific methodology, transgression can be interpreted as an offense for 'classical' science. We can conclude that the term transgression in English is not neutral, but has a somewhat negative connotation. However, the understanding of transgression is variable. Thus, the French philosopher M. Foucault in his essay 'A Preface to Transgression' comes to the paradoxical conclusion that 'transgression is profanity in a world that does not recognize the more positive sense of the sacred' (Foucault 1963: 29-52). Foucault is considered a 'meta-theorist' of the philosophy of transgression, which, in his opinion, should act as a cornerstone of the new philosophical (and cultural) paradigm. Just as the concept of 'contradiction' in its time was the basis of dialectical thinking, so should transgression be the basis for new thinking.

The main condition for transgression is the subject's autonomy, as well as the border itself, which must be overcome and which is a demarcation line that separates the outer from the inner, the essence from the phenomenon and the like.

In the context of human being, the transgressive transition breaks its tightness and, as L. Kiyashchenko points out, 'becomes a unifying medium of communication in which there are transdisciplinary and translinguistic exchange processes which involve reflection on value and regulatory grounds for scientific cognition' (Kiyashchenko 2005: 50).

Considering the above, transdisciplinarity does not act as the highest (third) level in the knowledge integration system. At large, the difference between transdisciplinarity and other forms of scientific knowledge integration is that the former focuses on contextualization, reflection, parameters of social acceptability and the formation of 'hybrid' forms of research teams that transform the principles of internal scientific expertise and the norms of ethical support for the production of knowledge. That is, transdisciplinarity provides for the interaction between science and other extra-scientific forms of knowledge.

\section{DEFINITION OF TRANSDISCIPLINARITY}

Cataloging approaches theoretical orientations and initiates further conceptualization, which allows one to clarify their discursive lines and semantic dominant. An attempt at such an analytical explication of concepts was made by R. Frodeman, J. T. Klein, C. Mitcham $<\ldots>$, which delineate five major interpretations of transdisciplinarity.

The first one is related to the problem of historical and philosophical search for holistic knowledge in the intellectual traditions of Ancient Greece, Medieval Europe and the Enlightenment. There were new contexts in the unity of a multifaceted and compositional world, focused on the 'complex' thinking and expansion of the established image of science. An example of this approach is the activity of the International Center for Transdisciplinary Studies (CIRET) (Frodeman et al. 2010: 24).

The second vector in transdisciplinarity is attributed to the critical attitudes that emerge in sociological and cultural studies when there is a transition from the text to the context that goes beyond class, gender, race, ethnicity, and any other identities. Transdisciplinarity is defined as a critical appraisal of terms, concepts and methods that, when transgressed across disciplinary boundaries, may be a means of higher levels of reflexivity (Frodeman et al. 2010: 25).

The third approach is the extension of the synthetic paradigm interpretation offered at the first conference 'Interdisciplinarity - Studies and Research Programs at Universities'. It is 
based on the ideas of the knowledge integrity and the need to reorganise its theoretical foundations and identify perspectives. According to its theorists, formation of transdisciplinary science is caused by the pooling of interdisciplinary resources in a single methodological and theoretical framework (Frodeman et al. 2010: 25).

The fourth line is a kind of 'trans-sector of transdisciplinarity' that emerged at the turn of the 1980s and 1990s in Germany and Switzerland when considering environmental issues. A key indicator of this approach is a particular focus on the living world and the involvement of stakeholders in the methodological framework of the knowledge and experience study (Frodeman et al. 2010: 25). Stakeholders can be defined and classified in many different ways. In their article, L. J. Bracken, H. A. Bulkeley and G. Whitman define them as non-academic people who have expertise related to an issue under study such as professional environmental managers (Bracken et al. 2015: 2). Stakeholders may be both social actors and groups of people, and their interest in solving the problem may vary. The basic point for this case is to identify mechanisms of interaction between the academic community, industry and business sector. In this context, transdisciplinarity can be seen as a synergy of perspectives between expert (academic) and every day (non-professional) cognitive strategies in solving problems. It is mainly about sustainable development issues and the risks of technological modernization.

The fifth trend, according to R. Frodeman, J. T. Klein and C. Mitcham, is presented by two theoretical approaches such as 'second type of knowledge production' (M. Gibbons and others) and 'post-normal science' (J. R. Ravetz, S. O. Funtowicz) (Frodeman et al. 2010: 25). The former was proposed in the work 'New Production of Knowledge: the Dynamics of Science and Research in Modern Societies' in 1994. The authors focused on the process of transition from the traditional disciplinary-organized type of knowledge production (Mode 1) to the new socially relevant and problem-oriented mode (Mode 2), which emerged as an appropriate answer to the complex nature of problems that have arisen in science and society (Gibbons 1994: 3).

J. Ravetz and S. Funtowicz associate the formation of post-normal science with global problems. According to the authors, real-world problems demonstrate the limited and one-sided disciplinary science organization. And therefore, in an era of increasing complexity scientific community needs additional cognitive resources of stakeholders and transdisciplinary strategies to effectively solve planetary problems (Funtowicz, Ravetz 1994: 1881).

Analysis of the approaches to the definition of transdisciplinarity makes it possible to say that transdisciplinary science as such does not exist. Transdisciplinarity is a form of knowledge integration that involves the cognitive resources of stakeholders to effectively solve planetary problems in an age of increasing complexity and uncertainty. The basis of the transdisciplinary project framework is its ability to combine the cognitive resources of science and knowledge of social actors, enshrined in values, ethical regulations, common sense and practical wisdom.

\section{ONTO-EPISTEMOLOGICAL PRINCIPLES OF THE TRANSDISCIPLINARY APPROACH}

Despite many philosophical and scientific studies on this subject, there are two dominant areas in Western European transdisciplinary research and methodological developments: ontological and methodological. The first direction is represented by the scientific work of the International Center for Transdisciplinary Studies (CIRET, Paris, France) with the guidance of B. Nicolescu. The second is the methodology of co-producing knowledge and development of 
conducting public forums practice on socially significant problems of the Network for Transdisciplinary Research (td-net) of the Swiss Academies of Arts and Sciences.

Theoretical developments formed within the activities of the Center for Transdisciplinary Studies are based on a conception that follows three methodological axioms:

1. Ontological axiom: There are different levels of object reality and, accordingly, different levels of subject reality.

2. Logical axiom: The transition from one level of reality to another is ensured by the logic of the included third.

3. The epistemological axiom: The structure of the levels of reality manifests itself in our knowledge of nature, society and individual existence as a complex structure: each level is what it is because all levels exist at the same time.

Putting the idea of multiple levels of reality into the concept of transdisciplinarity, Nicolescu relies on the ontological considerations of two great thinkers of the second half of the 20th century, philosopher N. Hartmann and physicist W. Heisenberg.

It is worth noting that physicist B. Nicolescu, like W. Heisenberg, concludes that there are levels of reality while thinking over the fundamental problem of physics, which is the incompatibility between quantum and classical mechanics (Nicolescu 2006: 11-12). By defining reality as 'anything that resists our experience, ideas, descriptions, images, or mathematical formalization', he essentially problematises the field of traditional ontology, outlining the possibilities of rethinking it (Nicolescu 2006: 12). The starting point of his ontological position is the epistemological assumptions about the fundamental inexhaustibility of our knowledge of nature.

Reality, understood in this way, involves understanding it as a multidimensional structure containing an infinite number of possible levels as the next step of theoretical conceptualization.

Having initially defined only two levels, Nicolescu later concludes that it is necessary to expand their number to infinity. He saw in this heuristic resource for understanding reality at the levels of language, ideas, matter and complexity. Another fundamental point in the conception of Nicolescu, which substantiates the concept of reality as a multilevel system, is related to the understanding of spheres that lie between and beyond the levels of reality.

Describing them as transparent topoi, the scientist claims that they all meet the limitations of our body and sense organs, regardless of what measuring instruments prolong these sense organs. The second problem inevitably arises in the course of the author's considerations and is related to the preconditions and conditions of knowing the levels of reality. It is expressed in the thesis about the principle knowledge of reality because of its correspondence to human cognitive capacities. Thus, Nicolescu's ontological and epistemological tenets, which substantiate the transdisciplinary model, are revealed in the structures of the transdisciplinarity of the object and its levels of reality, the transdisciplinarity of the subject and its levels of perception and the included third.

The logic of the 'included third' abandons the binary opposition characteristic of classical science and allows us to link the subject and its levels and the object and its levels in a single transformation. The new ontological order calls for other codes of thought and innovative approaches. These overcome the reductionism of classical science, which distinguished the social, economic and environmental spheres, leaving behind the individual, spiritual and cosmic levels of reality. The integrity of transdisciplinarity, grasping the unity of levels of reality, makes it clear that we are part of an orderly movement of reality. 


\section{THE METHODOLOGICAL APPROACH DEVELOPED BY THE SWISS SCHOOL OF TRANSDISCI- PLINARITY}

An interdisciplinary group of the Swiss Academies of Arts and Sciences organises project management and develops the online platform for transdisciplinary researches (Network for Transdisciplinary Research (td-net) of the Swiss Academies of Arts and Sciences). Unlike the French Center for Transdisciplinary Studies (CIRET), which develops an ontological and epistemological approach, it is developing a methodological approach. The transdisciplinary research methodology is based on the identification of three stages, each of which is related to the specificity of the problem and the potential for solving it: 1) identifying and structuring the problem; 2) problem analysis; 3 ) implementation of results. Structuring the process of research and delineation of each of the steps is aimed at clarifying the possible strategies, their elaboration or the conclusion about the irrationality of the transdisciplinary approach methodology in some cases.

Also, Swiss scientists have developed several principles aimed at optimising research. The first principle - reducing complexity - involves identifying the right knowledge and the people involved, in terms of practically oriented problems. The second principle - the achievement of efficiency through contextualization - is focused on the possible social implications of the project and its adaptation for understanding by non-specialists. The third principle - achieving integration in the process of open discussions - involves the perception of one's perspective as one of the possible ones, and therefore the evaluation of others as potentially acceptable. The fourth principle - the development of reflexivity through recursiveness - involves identifying each phase of the study as a kind of 'real-world experiment', the resource of which can be used in the further analysis, consideration, and structuring of the problem, as well as the subsequent adjustment of the original cognitive guides to the complex nature problems (Pohl, Hirsch Hadorn 2007: 20-22).

The methodological framework for transdisciplinary research is defined by social concern. Some approaches require the coordination of strategies and ways of addressing them for future resolution. On this basis, the purpose of transdisciplinarity is to develop empirical and practical knowledge frameworks aimed at solving, reducing or preventing problems in different areas of life.

Cognition involves crossing disciplinary boundaries, making it possible to connect the outer world of the object cognition and the inner world of its subject.

Based on the analysis of dominant areas, we can conclude that understanding the transdisciplinarity phenomenon and its scientific potential is possible through the prism of the onto-epistemological and methodological approaches that complement each other and confirm the scientific status of transdisciplinary research.

\section{CONCLUSIONS}

Thus, the formation and development of transdisciplinarity as a new type of knowledge integration was determined by the differentiation of science, as well as the possibility of interaction of different cognitive models and strategies in solving complex socially significant problems. Working in the cross-border communicative mode of interaction of various scientific and extra-scientific cognitive practices, the transdisciplinary approach extends the principles of classical and non-classical science to post-non-classical rationality, focused on taking into account the value and purpose parameters of scientific knowledge, as well as complex issues 
that modern practice-oriented science deals with. Unlike other modern forms of knowledge integration, transdisciplinarity focuses on contextualization, reflection, social acceptability and the formation of 'hybrid' forms of research teams that involve the cognitive resources of stakeholders to effectively solve planetary problems whenever they arise. Transdisciplinarity does not oppose disciplinary models of knowledge and is not a higher level of integration, but complements interdisciplinarity and multidisciplinarity approaches to research, i.e. involves a fundamental complement to each form of knowledge and, consequently, the ability to build a common methodology.

In Western European transdisciplinary research, two dominant areas can be identified: onto-epistemological and methodological. The former is represented by the scientific work of the International Center for Transdisciplinary Studies (CIRET, Paris, France) with the guidance of B. Nicolescu. His theoretical constructions are based on three methodological postulates: the existence of levels of reality, the logic of the included third and complexity. The second area is the methodology of co-producing knowledge and development of conducting public forums practice on socially significant problems of the Network for Transdisciplinary Research (td-net) of the Swiss Academies of Arts and Sciences. The methodological framework of the Swiss School of Transdisciplinarity includes the following principles: reducing complexity; achieving efficiency through contextualization; achieving integration in the process of open discussions; the development of reflexivity through recursiveness. Based on the analysis of dominant areas, we can conclude that the purpose of transdisciplinarity is to develop empirical and practical guidelines for knowledge aimed at solving, reducing or preventing problems in various spheres of life. Achieving this goal involves identifying relevant issues, taking into account the complexity, different perspectives of the relationship between abstract and local knowledge, as well as practices aimed at achieving the common good. Attention to these requirements is also aimed at integrating different cognitive and value perspectives through the involvement of social actors interested in the research process.

Received 9 March 2020

Accepted 2 July 2021

\section{References}

1. Bracken, L. J.; Bulkeley, H. A.; Whitman, G. 2015. 'Transdisciplinary Research: Understanding the Stakeholder Perspective', Journal of Environmental Planning and Management 58(7): 1291-1308.

2. Defila, R.; Di Giulio, A. 2015. 'Integrating Knowledge: Challenges Raised by the Inventory of Synthesis', Futures 65: 123-135.

3. Di Giulio, A.; Defila, R. 2017. 'Enabling University Educators to Equip Students with Inter- and Transdisciplinary Competencies', International Journal of Sustainability in Higher Education 18(5): 630-647.

4. Foucault, M. 1963. 'A Preface to Transgression', in Language, Counter-memory, Practice. New York, NY: Cornell University Press, 29-52.

5. Frodeman, R.; Klein, J. T.; Mitcham, C. 2010. The Oxford Handbook of Interdisciplinarity. Oxford: Oxford University Press.

6. Funtowicz, S. O; Ravetz, J. R. 1994. 'Uncertainty, Complexity and Post-normal Science', Enviromental Toxicology and Chemistry 13(12): 1881-1885.

7. Gibbons, M.; Limoges, C.; Nowotny, H.; Schwartzman, S.; Scott, P.; Trow, M. 1994. The New Production of Knowledge: The Dynamics of Science and Research in Contemporary Societies. London: Sage.

8. Kiyashchenko, L. P. 2005. 'Ethos of Post-non-classical Science (to the Statement of the Problem)', Filosofiya nauki i tekhniki 11: 29-54.

9. Lattuca, L. R. 2003. 'Creating Interdisciplinarity: Interdisciplinary Research and Teaching Among College and University Faculty', History of Intellectual Culture 3(1): 1-20.

10. Lawrence, R. J. 2004. 'Housing and Health: From Interdisciplinary Principles to Transdisciplinary Research and Practice', Futures 36(4): 487-502. 
11. Nicolescu, B. 2006. 'Heisenberg and the Levels of Reality', European Journal of Science and Theology 2(1): 9-19.

12. Piaget, J. 1970. 'General Problems of Interdisciplinary Research and Common Mechanisms', in Main Trends of Research in the Social and Human Sciences, Pt. 1: The Social Sciences. Paris: UNESCO, 467-528.

13. Pohl, C.; Hirsch Hadorn, G. 2007. Principles for Designing Transdisciplinary Research - proposed by the Swiss Academies of Arts and Sciences. Miinchen: oekom verlag.

14. Remadier, T. 2004. 'Transdisciplinarity and Its Challenges: The Case of Urban Studies', Futures 36(4): 423-439.

15. Rudhumbu, N.; Zhou, L.; Nhundu, K. 2017. 'Transdisciplinary Research in Higher Education: Towards a Paradigm for Sustainable Development', IOSR Journal of Business and Management 19(1): 13-19.

16. Transgression. The American Heritage Dictionary of the English Language, Fifth Edition Copyright. Available at: https://ahdictionary.com/word/search.html?q=Transgression+

\title{
Transdiscipliniškumo apibrèžimo problema ir transdisciplinarinès prieigos galimybès post-ne- klasikiniame moksle
}

\begin{abstract}
Santrauka
Pagrindinis šio straipsnio uždavinys - pateikti nuodugnią teorinę transdiscipliniškumo reiškinio analizę. Autoriai atliko lyginamajjį esminių šiuolaikinio mokslinio žinojimo integracijos formų tyrimą. Straipsnyje apmąstomi pagrindiniai transdiscipliniškumo apibrěžimo būdai. Ištirtos Vakarų Europos tarpdisciplininiuose tyrimuose ir jiems skirtuose metodologiniuose darbuose vyraujančios sritys - ontologinè ir metodologinè. B. Nicholescu ontoepistemologinès prieigos analizè leido daryti išvadą, kad, skirtingai nei atskiri mokslai, tiriantys konkrečius realybės fragmentus ar lygmenis, tarpdisciplininè strategija yra pastanga suprasti kokio nors proceso dinamiką, žvelgiant ị jị vienu metu iš kelių tikrovès lygmenų perspektyvos. Štai kodèl ši strategija peržengia atskirų mokslų ribas ir sukuria visapusišką tiriamojo proceso vaizdą. Straipsnyje taip pat nubrèžiami metodologiniai transdisciplininio tyrimo rèmai ir nusakomas jo specifiką atitinkantis tikslas. Prieinama prie išvados, kad pasiekti šį tikslą ịmanoma tik ịvykdžius tam tikrus reikalavimus.
\end{abstract}

Raktažodžiai: transdiscipliniškumas, tarpdiscipliniškumas, daugiadiscipliniškumas, ontoepistemologinè prieiga, metodologinè prieiga 